30 years, to be shared with readers, and it is gratifying to find that the emphasis on care and treatment, which has been a welcome feature through successive editions, has been retained. The standard of description is high and the only part of the book which makes rather poor reading is the revised account of atelectasis, especially the section dealing with idiopathic respiratory distress. Perhaps when the book is next revised the author will consider refashioning this important, and inevitably rather tentative, section. By then there may also be a place for a little more detail about temperature regulation in the newborn, especially in the premature infant. There is a valuable account of hæmolytic disease of the newborn followed by one on kernicterus due simply to hyperbilirubinæmia of prematurity. Not all workers would accept Dr. Crosse's indications for exchange transfusion in those jaundiced cases without evidence of hæmolysis. These are small criticisms of a book which can be highly commended.

Clinicopathological Conferences of the Massachusetts General Hospital Selected Medical Cases

B. Castleman, M.D., and H. Robert Dudley, JR., M.D. Pp. 295. London: J. \& A. Churchill.

This beautiful book is a collection of 50 case reports from the well-known regular series in the New England Fournal of Medicine. Several of the earlier ones are of great historic interest and are followed by brief addenda written many years later, often by the original commentator. Thus Dr. Walter Bauer, discussor of the first case, of abnormal calcium metabolism presented in 1936 , adds a postscript 24 years later. Another case of great interest is one of virilism, diabetes and osteoporosis, discussed by the late Dr. Soma Weiss in 1937 , three years after Kepler's presentation of three cases of suprarenal cortical syndrome with pituitary basophilism at the Mayo Clinic.

All these discussions are fascinating to read and make an instructive change from textbooks and papers, for not only does one grasp how the clinical history unfolded, one comes to appreciate how a really competent clinician evaluates the evidence and hammers out a diagnosis-usually with the pathologist there to supply the last word. The amount of sheer clinical 'know-how' packed into these pages is enormous.

Each report is illustrated with X-rays, ECGs and photographs and followed by a reference list.

\section{Calcium Metabolism and the Bone}

Paul Fourman, M.D., D.SC., F.R.C.P. Pp. 325. Oxford: Blackwęll Scientific Publications. 37s. $6 d$.

Dr. Fourman has placed all postgraduates in his debt by filling a real need for an authoritative work on this subject with this brilliant book. The amount of hard work that must have gone into it is prodigious, and it is clearly written, well set out and fully documented with 75 pages of references, as well as a good index. The standard of production is also excellent, so that careful reading has revealed only a very few misprints. Everyone who is interested in this subject-and everyone is-should buy this book.

\section{Quantitative Cellular Hæmatology}

J. M. Yoffey, D.SC., M.D., F.R.C.S.(ENG.). Pp. xv + 122, illustrated. Springfield, Illinois: Charles C Thomas. Oxford: Blackwell. rg6o. 44s.

The title of this book is really a misnomer, since it touches only briefly on all the formed elements of the blood other than the lymphocyte and then only in relation to the author's well-known views on the lymphocyte as the totipotential cell. This concept, of which Maximow was one of the major proponents stated at great length for so short a book, and althou some of the conflicting evidence is mentioned, especiâfly that derived from studies of recirculation by Gowans and others, there is a lack of balance in the presentati $\overrightarrow{\text { on. }}$.

Dr. Yoffey quotes the original and an English translation of Maximow's statement about the totipotentiaty of the small lymphocyte. This is a classical exampleof 'I say it, therefore it must be so'. The quality $\overline{\bar{c} 0}$ f this pronouncement is evident in the light of subseque events; over 50 years later there is still no decisfie evidence about the origins of the various blood cells

Dr. Yoffey's readable monograph is a useful statement of his own position, has a good bibliography, åd should have no real dangers for the reader experience्td in the field of hæmatology.

\section{The Day Hospital Movement in Great Britairfo}

JAMES FARndale, B.Com., F.H.A., M.R.S.H.t., Barrister-at-Law. Pp. xvii +430 , illustrateg. Oxford: Pergamon Press. 1961. 84s.

The steady development of the day hospital movemênt has been an important feature of the advance in post-war social medicine in Great Britain, and Mr. Farndales interesting study of the subject will be of the greatest value to all concerned with the establishment and administration of this type of patient care.

In the first half of his book he examines the organis tion and function of day hospitals; the second half is devoted to a detailed description of 65 day hospitals aरु day centres visited in $1958-59$, presented in a tabulated form for easy reference and comparisons. An extegsive bibliography, maps and index are included.

The book is a report on a research project carrie⿶ ont under the auspices of the University of Manchestepand The Bethlem Royal Hospital and the Maudstey Hospital, London. Clinical aspects were not includsd in the investigation. With considerable skill, time agd industry, the author has succeeded in producing a comprehensive and balanced assessment of the services nofw provided within the three broad categories of psychiatric day hospitals, (b) geriatric day hospitals a (c) medical and industrial rehabilitation centres a welfare centres. Particular attention is given to capifal and maintenance costs and their relationship to the cost of in-patient services, to the transport arrangements for day patients, to the method of supply of drugs, and $\$ 0$ catering services and charges.

The evidence suggests that in maintenance cost di. patients are cheaper than in-patients, but no firen conclusions are drawn because of the great variations in the types of institutions and the services given, variety which may be a reflection of the gaps still to found in the treatment of the mentally-ill and in tbe care of old people. Although at present on a small scale, the work carried out by day hospitals and dify centres is impressive, and there is every indication that they will play an increasingly important part in 'the present trend towards treatment outside institutions afpd keeping people in hospital for minimal periods as patients '. No clear-cut picture of the day hospital of the future emerges, and indeed at this formative stage tore existing diversity in practice and administrative setting not a bad thing. Mr. Farndale makes a number of constructive suggestions. He believes that there is scoge for further experiment and development of facilities $r$ old people, and that a capital sum of $\oint_{1} I_{2}^{\frac{1}{2}}$ million might usefully be spent in providing approximately 50 additional day hospitals and day centres for psychiatioc patients, and another $£ 500,000$ might be requirgd annually for their maintenance and staffing. 